\title{
A War Against Disease and Despair: Immigrants, Nurses, Soldiers, and the Transformation of Patient Care on Ellis Island During World War I
}

\section{By Ryan Radice}

\section{DOI: $\underline{\text { https://doi.org/10.14713/njs.v7i1.241 }}$}

Located on what is today New Jersey soil, the hospital facilities on Ellis Island, run by the Public Health Service (PHS) to treat immigrant patients, were a medical marvel of their time. While known primarily for its use as an immigration facility, Ellis Island went through several major changes from the time war was declared in Europe in 1914, to the time that the last military members left the Island in 1919. During the First World War, Ellis Island and its associated hospital facilities would be the victims of German terrorism, a mobilization point for thousands of Red Cross nurses bound for the frontlines, and a debarkation hospital that was the first stop home for countless sick and wounded soldiers returning from the battlefield. This paper examines how the PHS, the Red Cross, and the Army Medical Corps tried to protect public health, screen immigrants for disease, and care for our military casualties, all under the tension and strain of a world war and a global pandemic.

The First World War arrived at Ellis Island with a bang. As the early hours of Sunday, July $30^{\text {th }}, 1916$ passed, none of the employees or patients in the Ellis Island hospital, or the immigration staff and immigrants temporarily detained, could have imagined one of the most notorious acts of international terrorism on American soil would take place within sight of the island. ${ }^{1}$ Today, a small plaque in Liberty State Park marks the site of Black Tom Island, a manmade wharf situated just to the south of the Statue of Liberty. ${ }^{2}$ By July, 1916, the wharf stored nearly two million

\footnotetext{
${ }^{1}$ Harlan D. Unrau, Historic Resource Study (US Department of the Interior/ National Park Service, 1984), $767-768$.

2 Adam Bieneick and Kate Lyons, "Black Tom Island: Germany Secretly Attacks U.S during WWI,"

Worldwarlcentennial.org, 2016, https://www.worldwar1centennial.org/index.php/communicate/press-media/wwicentennial-news/1295-black-tom-island-germany-secretly-attacks-u-s-during-wwi.html (accessed October 7, 2019).
} 
pounds of munitions and explosives, including TNT, artillery shells, and small arms munitions destined for the frontlines overseas. Though the United States was officially neutral for most of the conflict, technically open to trading with both sides, a significant trade imbalance was in play. British blockades of German ports resulted in American-German trade falling to a mere 10 percent of what it had been prior to the war. Conversely, American trade with Britain and France increased nearly 300 percent. $^{3}$

The infusion of American munitions and supplies (the majority of which went to the Allies), gave the Allies a significant logistical advantage. Thus, the German government devised a mission to cripple American efforts to trade with the Allies. A well-established German espionage operation within the United States aided these efforts, and Black Tom Island was a natural target for attack. Saboteurs hatched a plot to destroy the wharf, all at the direct prompting of none other than the Imperial German ambassador to the United States, Count Johann Von Bernstorff. ${ }^{4}$

In the early morning hours of July $30^{\text {th }}, 1916$, patients at the Ellis Island hospital slept and convalesced peacefully in bed, warm summer breezes flowing into the wards through open windows. They were oblivious as German saboteurs snuck onto Black Tom Island carrying pencil bombs and dynamite. At approximately 2:08 a.m., Black Tom Island erupted in flame. The ignition of the island's two million pounds of munitions created an explosion unprecedented in scale. Plate glass, all the way to Times Square in Manhattan, was shattered. Citizens of Maryland were reportedly awakened by this event. On the Richter scale, this would have registered at nearly $5.5 .^{5}$ For those on Ellis Island, the scene they awakened to must have been terrifying, chaotic, and

\footnotetext{
${ }^{3}$ Ibid.

${ }^{4}$ Ibid.

${ }^{5}$ Unrau, 768.
} 
captivating, all at once. Chief Nurse Margaret Daly recorded in her memoir, "We all expected to be blown to eternity." "6lack Tom Island was less than a mile south of Ellis Island, meaning the hospitals on the south side of the island were in particular danger. ${ }^{7}$ There were approximately 39 patients in the contagious disease hospital, 90 patients in the general hospital, 353 detained immigrants housed inside the main building, along with about 125 staff. $^{8}$ The first thing they would have seen were the windows, propped open to allow in the warm harbor breezes, suddenly blown out. Flying glass would have filled the air as the windows in many cases were blown from their sashes. The New York Times reported on some of the damage the following day. The article states:

There was not a window left in the sashes of the Contagious Diseases Hospital, and the five bathrooms were practically turned inside out by the concussion. Taps were wrenched off, pipes twisted like pieces of paper, and the baths lifted bodily from their bars and rivets and turned completely over. ${ }^{9}$

The explosion damaged all three of the Ellis Island buildings. ${ }^{10}$ In some places, the terra cotta roofs of the hospitals had caved in, "as if it had been done by a Jack Johnson." But this was just the beginning. For the next three hours, as Black Tom continued to burn, artillery (some in the form of 3-inch shells) and shrapnel fell on Ellis Island. The 125 staff members on duty organized an evacuation. The 353 detainees inside the main building were placed on board the ferry boat Ellis Island, and brought to the Battery in lower Manhattan under police guard. ${ }^{11}$ Hospital patients did not leave the island. Rather, the combined 129 patients were evacuated outside the buildings. Patients remained separate, (according to their diagnosis). Accounts suggest the general hospital

\footnotetext{
${ }^{6}$ Margaret V. Daly, Nursing at Ellis Island: A Memoir (New York, n.d.), (Shared with the author courtesy of Dr. Arlene Keating, Dr. Michele Hehman, and Jim Peskin, 1/8/2020), 8.

${ }^{7}$ Unrau, 768.

8 "Ellis Island Like War-Swept Town," New York Times (1857-1922), Jul 31, 1916. https://ezproxy.monmouth.edu/login?url=https://search-proquestcom.ezproxy.monmouth.edu/docview/97874734?accountid=12532. (accessed, November 2, 2019).

${ }^{9}$ Ibid.

${ }^{10}$ Unrau, 768.

11 "Ellis Island Like War-Swept Town,” New York Times, Jul 31, 1916.
} 
patients were brought to the eastern end of island No.2, into an area where there were tennis courts with an adjacent garden. The contagious patients were likewise evacuated from the buildings, though there is some uncertainty where they were positioned once outside. ${ }^{12}$

The doctors and nurses of the US Public Health Service did their best to organize and calm the patients. There were a great variety of conditions among the patients, and it was the psychiatric patients (housed in the general hospital) who presented one of the strangest scenes of the entire night. ${ }^{13}$ Assistant superintendent of the hospital, Frederick A. Theis, recalled:

Acting in conjunction with my associates, I hastened to assist in the removal of our insane patients to the tennis courts. We wrapped them in blankets and carried them out into the open air. When we had them out of doors, they presented one of the most extraordinary spectacles I have ever seen. As the five-inch shells flared over the island like skyrockets, the poor demented creatures clapped their hands and cheered, laughed and sang and cried, thinking it was a show which had been arranged for their particular amusement. ${ }^{14}$

As if handling them during the explosion was not taxing enough, Theis's account suggests the real difficulty was after the explosion had stopped. He continued, "We bivouacked on the tennis court for the rest of the night, vainly trying to pacify the insane who were disappointed that the show was over. At 7:00 A.M., we cleaned up and returned the patients to the hospital."15

Despite all that had transpired, peril was still close at hand. Barges laden with munitions were waiting for transfer to larger ships. During the explosion, they caught fire and burned through their mooring ropes. An incoming tide, westerly wind, and a wave from the explosion, sent these flaming, exploding barges drifting towards Ellis Island. ${ }^{16}$ Four "blazing lighters" drifted into the southwest area of the seawall, down by the powerhouse of the contagious disease hospital, catching

\footnotetext{
12 The Survey, "Ellis Island Cool Under Showers of Shrapnel.” The Survey 36 (August 1916): 486-487.

13 Unrau, 771.

14 Ibid.

${ }^{15}$ Ibid., 772.

16 Ibid.
} 
the cribbing of the seawall on fire ${ }^{17}$ In one of many heroic actions taken that night, the contagious disease hospital's superintendent James A. Lee, with the help of his courageous doctors, rushed to the scene wielding fire hoses to save the hospital building. The New York Times reported:

James A. Lee, Superintendent of the Contagious Diseases Hospital, with Drs. Carl Ramos, Joseph A. Wilson, Evans Tremble, and James A. Farris played the hose on the blazing lighters for two hours before there was sufficient water to permit the fireboat New Yorker to get within reach. Mr. Lee, who was cut on the nose by flying glass, said that four blazing lighters drifted down to the hospital wall and the staff kept the hose on them until they drifted on toward Communipaw. One sunk a little way from the shore, however. Two other burning barges passed the hospital and grounded in the shallow water 500 feet to the north of Ellis Island. ${ }^{18}$

It must have been a sight as these barges floated past Ellis Island, crackling with exploding munitions that rained shrapnel upon the buildings. Courage was hardly in short supply that night, as numerous fireboats attempted to douse the burning barges from distances as short as 13 feet. ${ }^{19}$ Tugboats of the Lehigh Valley Railroad Company arrived and managed to tow two flaming barges that had floated into the hospital's seawall. Theis attested later, "Fortunately, the heroism of those who manned the tugs of the Lehigh Valley Railroad saved us. They towed the two flaming barges out to sea, where they sank amid concussions which sounded like the end of the world." ${ }^{20}$

One cannot help but be astonished at the level of destruction and the wild scenes that transpired that night on Ellis Island. Theis summed it up, saying, "Nothing nearer a 'hell on Earth' could be imagined." ${ }^{21}$ What is most astonishing (one could even say miraculous), is that there were no deaths on the island, only minor injuries. The Times reported that two nurses and two men received slight facial cuts from falling glass, and that two patients received cuts to the hands and

\footnotetext{
17 "Ellis Island Like War-Swept Town," New York Times, Jul 31, 1916.

${ }^{18}$ Ibid.

${ }^{19}$ Ibid.

${ }^{20}$ Unrau, 772.

${ }^{21}$ Ibid., 771.
} 
face without any serious injuries. ${ }^{22}$ Some staff suffered bumps and impact related injuries, as they were standing when the explosion occurred and were thrown by the blast against walls, floors, and furniture. ${ }^{23}$ Both the Times and Theis's account suggest Chief Clerk Sherman's office pet, a black kitten named Toto ${ }^{24}$ received the worst injury in a wound to one of his legs, possibly from flying glass or even grazing by a bullet (he was quickly bandaged up by a surgeon). ${ }^{25}$

Unlike the inhabitants, the buildings were not so lucky. Initial estimates for repairs went up to $\$ 150,000$. This proved a low estimate, as structural damage required much more work. By June of 1917 , about $\$ 400,000$ had been spent on repairs to the hospital buildings and the main building. ${ }^{26}$ Still, there are indications that the damage could have been far worse. The Annual Report of the Commissioner General of Immigration (1917) speculates, "Had the explosion occurred at any other time than during the summer months the administration building and the hospitals probably would have been a mass of wreckage; for the buildings were open at the time, which saved them from demolition from the concussion. ${ }^{.27}$ Beyond the health benefits of airflow from open windows and doors espoused by the PHS, it seems there was a second, unexpected benefit on that fateful night.

Whether organizing an evacuation of hospital patients with a multitude of contagious diseases, wielding firehoses against flaming ammunition barges, or pacifying psychiatric patients who were disappointed that their "fireworks show" was over, the men and women of Ellis Island showed their true grit. Dr. J.C. Perry, chief medical officer, stated with resolve, "Great credit is due to the hospital staff and attendants. Yet what is the service for? If I didn't know that those men

22 "Ellis Island Like War-Swept Town," New York Times, Jul 31, 1916.

${ }^{23}$ The Survey, "Ellis Island Cool Under Showers of Shrapnel," 486-487.

24 "Ellis Island Like War-Swept Town," New York Times, Jul 31, 1916.

${ }^{25}$ Unrau, 772.

${ }^{26}$ Ibid.

${ }^{27}$ Ibid., 773. 
and women were equal to an emergency, they would not be there." 28 As the sun rose over the island, the detainees returned from the Battery. Patients were escorted back into the shaken hospital, where temporary mosquito netting was hung in the windows to replace the pulverized glass. The staff began to sweep up the glass and rubble, and tried, in the short term, to make the buildings as livable as possible. ${ }^{29}$ Despite a surreal start to their Sunday morning, they carried on dutifully in their work.

\section{A Hospital for All Nations}

Ellis Island is an American icon. Some 12 million immigrants arrived there, with millions of Americans today related to one of them. ${ }^{30}$ What often goes unmentioned is the complex of buildings that still stand today on Ellis Island's south side. Collectively known as The Ellis Island Hospital, it was administered by the United States Public Health Service to treat immigrant patients pulled from the line during inspection for "loathsome and contagious diseases" and other conditions of infirmity. ${ }^{31}$ However, medical care and Ellis Island's mission changed dramatically during the First World War. Ellis Island's facilities underwent major changes in their operation, shifting the focus from processing immigrants to mobilizing Red Cross nurses, and treating thousands of wounded American servicemen returning from France. The Ellis Island Hospital contributed immensely to the effort to win the war, and the struggle to care for those who gave so much of themselves to win it. What follows will shine a light on an overshadowed area of Ellis Island's history, and bring to light some remarkable stories of service and dedication by those who lived, worked, and were treated there during this important period.

\footnotetext{
28 The Survey, "Ellis Island Cool Under Showers of Shrapnel," 487.

${ }^{29}$ Ibid., 486.

${ }^{30}$ Save Ellis Island, “Ellis Island's History”, Saveellisisland.org, https://saveellisisland.org/about-us/blog/item/50ellis-island's-history (accessed October 30, 2019).

${ }^{31}$ Lorie Conway, Forgotten Ellis Island (New York: HarperCollins Publishers, 2007), 6-13.
} 
To understand how medicine on the island changed during the war, one must understand its original role. Ellis Island opened in 1892 as a port of entry to which immigrants were funneled for more effective screening. Public health issues arising from the period's mass migration were at the forefront in determining immigration policy. ${ }^{32}$ Rigorous inspection for "loathsome and contagious diseases" fell to the United States Public Health and Marine Hospital Service (shortened to the United States Public Health Service prior to WWI). The PHS viewed public health as a matter of national security, and approached medical inspections with a high-degree of organization. ${ }^{33}$ Inspection for quarantinable diseases such as cholera, yellow fever, typhus, and plague took place aboard the steamships at Hoffman and Swinburne Islands (situated beyond the modern Verrazano Bridge, off Staten Island). ${ }^{34}$ A general inspection of first and second class passengers also took place on board, leaving them free to land once the steamship pulled into port. Third class and steerage passengers were processed at Ellis Island. ${ }^{35}$

For those landing at Ellis, the medical inspection was often a speedy affair given to the few hundred to several thousand people per day being inspected. Immigrants were ushered single file through a series of fences. A PHS medical officer observed the patient from their feet to their head, for any telltale signs of illness or infirmity. Obvious giveaways such as a face rash could indicate measles. Less obvious signs, such as a mother carrying a child who should be old enough to walk, could indicate the child was paralyzed. Inspections for trachoma fell to another medical officer a short distance away. Trachoma (which causes blindness) forms visible scar tissue underneath the infected person's eyelids. The officer typically used a button hook to gently lift up, and roll back,

\footnotetext{
${ }^{32}$ Conway, 3-9.

${ }^{33}$ United States Public Health Service, "History," Usphs.gov, https://www.usphs.gov/aboutus/history.aspx (accessed October 30, 2019).

${ }^{34}$ Amanda Aroncyzk, "Photos: The Strange History of NYC's Swinburne and Hoffman Islands," Gothamist.com, November 28, 2018. https://gothamist.com/arts-entertainment/photos-the-strange-history-of-nycsswinburne-and-hoffman-islands (accessed October 30, 2019).

35 "Ellis Island's History," Saveellisisland.org.
} 
the immigrant's eyelid, cleaning the hook each time with a disinfectant. ${ }^{36}$ Due to vast numbers, the examination often lasted under one minute per person. ${ }^{37}$ Those suspected of a condition were marked with chalk and sent for closer scrutiny in an exam room. ${ }^{38}$

When Ellis first opened, a small infirmary existed within the scope of the main building. This proved utterly insufficient, and a larger hospital complex was necessary. To build the hospital, two new islands were constructed right next to Ellis Island. The general hospital went up first, in stages. Completed by 1910, it contained about 275 beds (which was nearly three times the size of a common city hospital of that time), as well as four operating rooms, a delivery room, a "psychopathic pavilion" (for mental cases), laundry, and a morgue. This hospital was intended for the treatment of non-contagious patients. ${ }^{39}$

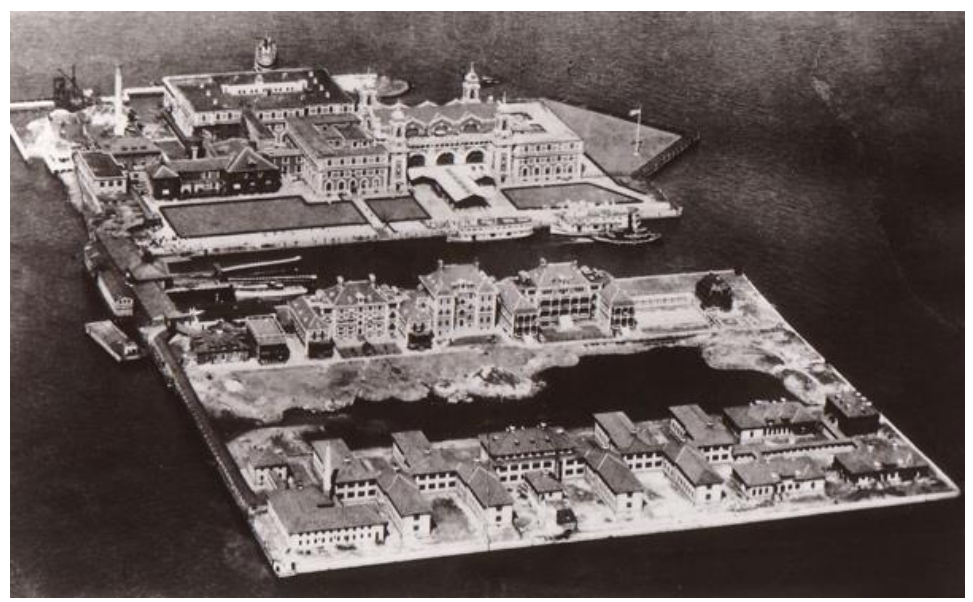

Aerial view of Ellis, 1920s, with the hospitals on separate islands. Courtesy of Save Ellis Island.
The contagious disease hospital opened in 1911, eliminating the problem of treating contagious patients in local, off-island hospitals. ${ }^{40}$ The hospital on Island No.3 was separated from the general hospital by 200 feet of water (largely due to a common belief at the time that disease could not spread over a large body of water). ${ }^{41}$ This hospital was the culmination of the pavilion style, where patients are separated and grouped by disease. Appearing in the mid- $19^{\text {th }}$ century, this

\footnotetext{
${ }^{36}$ Conway, 32-39.

37 "Ellis Island's History," Saveellisisland.org.

${ }^{38}$ Conway, 32.

${ }^{39}$ Ibid., 3-8.

${ }^{40}$ Unrau, Historic Resource Study, 598-599.

${ }^{41}$ Conway, 9.
} 
style was espoused by Florence Nightingale, and was used widely during, and after, the American Civil War. ${ }^{42}$

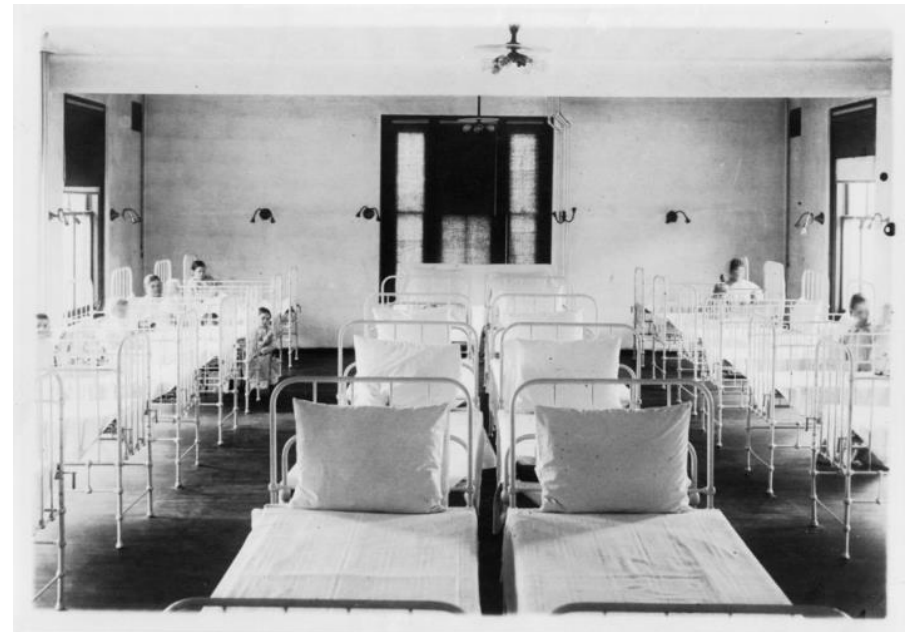

Children's ward, Contagious Disease Hospital. Courtesy of Save Ellis Island.
In pavilion-style hospitals such as Ellis Island, patients received as much fresh air and sunlight as possible. The windows of the contagious disease hospital were open nearly 18 inches wide (with a muslin or burlap covering), year round and in all weather. ${ }^{43}$ The contagious disease hospital consists of 11 pavilions with 22 wards that jut off a central corridor

two football fields in length. ${ }^{44}$ Wards for scarlet fever, measles, whooping cough, favus, trachoma, tuberculosis, and diphtheria were intentionally off-set from each other: a precaution against infected air from one entering another. ${ }^{45}$ The facility also contained a power house, laundry, mattress sterilizer, morgue, and state-of-the-art laboratory manned by officers of the PHS (trained in bacteriology) who conducted spinal fluid tests, diphtheria cultures, tuberculosis and meningitis tests, and much more. ${ }^{46}$ The facilities were staffed by approximately 150 people, ${ }^{47}$ and the care provided by them was exceptional, something clearly seen in the hospital's statistics. In 1913, for

\footnotetext{
${ }^{42}$ William T. Campbell, "The Pavilion-Style Hospital of the American Civil War and Florence Nightingale," Civilwarmed.org, July 8, 2019. http://www.civilwarmed.org/surgeons-call/pavilionhospitals/ (accessed October 30, 2019).

${ }^{43}$ J. G. Wilson, "The Contagious Disease Hospital for Immigrants At Ellis Island, N.Y," The Modern Hospital 9 (November, 1917): 315.

${ }^{44}$ Jim Peskin, Personal communication, 1/23/2020.

${ }^{45}$ Conway, 9.

${ }^{46}$ Unrau, 749-750.

${ }^{47}$ Department of Commerce-Bureau of the Census, Fourteenth Census of the United States: 1920-Population (Ellis Island, New York Harbor). Sent by personal communication from Jim Peskin on 12/5 2019.
} 
example, 10,381 patients were admitted to both hospitals, with 277 dying. ${ }^{48}$ The average mortality rate for that year was just 2.6 percent; quite remarkable in an era before the advent of modern antibiotics.

The outbreak of the war in Europe quickly affected the medical side of Ellis Island's operations, especially for the PHS officers who worked the line inspection. In the fiscal year of 1914 (which ended on June $30^{\text {th }}$, before the war's outbreak), 1,009,854 alien passengers entered the port of New York for inspection. ${ }^{49}$ The war ended a trend of nearly one million immigrants entering the United States every year. ${ }^{50}$ The dramatic drop in immigration allowed for longer inspections per immigrant. By 1915, inspection time per immigrant stood at approximately 40 seconds (actually an increase over previous years). On some days, numbers were so light that an entire ship's worth of steerage passengers could be inspected in private exam rooms instead. Longer inspections naturally meant that medical certificates for physical and mental conditions increased. ${ }^{51}$

The war also brought change to the contagious disease hospital's laboratory. Since it opened in 1911, the laboratory had been used extensively for diagnostic work, particularly for tuberculosis. Deportable diseases like tuberculosis required laboratory work to certify a diagnosis. Ellis Island's Commissioner, William Williams, stated emphatically, "No case of pulmonary tuberculosis will be certified as 'dangerous contagious,' unless the clinical symptoms are well marked and the tubercle bacillus has been found in the sputum." ${ }^{, 2}$ While still used for diagnostic

\footnotetext{
${ }^{48}$ United States Public Health Service, Annual Report of the Surgeon General of the Public Health Service of the United States, For the Fiscal Year 1913 (Washington D.C.: Government Printing Office, 1914), 160.

${ }^{49}$ United States Public Health Service, Annual Report of the Surgeon General of the Public Health Service of the United States, For the Fiscal Year 1915 (Washington D.C.: Government Printing Office, 1915), 189.

${ }^{50}$ National Park Service, "Immigration and the Great War," Nps.gov, October 30, 2018, https://www.nps.gov/articles/immigration-and-the-great-war.htm (accessed November 2, 2019).

${ }^{51}$ Annual Report of the Surgeon General of the Public Health Service of the United States, For the Fiscal Year 1915, 189-204.

${ }^{52}$ Conway, 22.
} 
work, the first years of the war saw the laboratory used for medical research activities as well. PHS personnel experimented by inoculating various diseases into animal test subjects. Animals were inoculated with commonly seen diseases like trachoma, scarlet fever, and mumps, accompanied by cultural studies, presumably to develop more effective treatments. ${ }^{53}$ Unfortunately, documentation is scarce regarding what, if any, conclusions came from these studies. Clearly, wartime conditions allowed for a shift in the laboratory from purely diagnostic work to research and experimentation.

By 1916, the laboratory's work had increased nearly four times what it was in 1915, with some 5,216 specimens examined. ${ }^{54}$ War-time conditions also meant that people with certain deportable diseases such as trachoma and ringworm of the nails and scalp could not actually be deported. They were instead treated in the hospital, and their treatments seem to have been successful in the eyes of the PHS. The hospital reported 56 (out of 64) cases of trachoma resulting in recovery after treatment, and another 28 cases of ringworm of the nails cured as well. ${ }^{55}$

\section{These Heroes Wear Capes: The Red Cross on Ellis Island}

When the United States finally declared war in April of 1917, the role of Ellis Island changed dramatically. As the chief nurse noted, "Ellis Island in 1917 presented a martial appearance." ${ }^{, 56}$ Immigrant patients and PHS staff now had to share the space with interned Germans and thousands of nurses mobilized by the American Red Cross for service in the Army

\footnotetext{
${ }^{53}$ Annual Report of the Surgeon General of the Public Health Service of the United States, For the Fiscal Year 1915, 205.

${ }^{54}$ United States Public Health Service, Annual Report of the Surgeon General of the United States Public Health Service, For the Fiscal Year 1916 (Washington D.C.: Government Printing Office, 1916), 215.

55 Ibid.

${ }^{56}$ Lavinia L. Dock, History of American Red Cross Nursing (New York: The Macmillan Company, 1922$), 419$.
} 


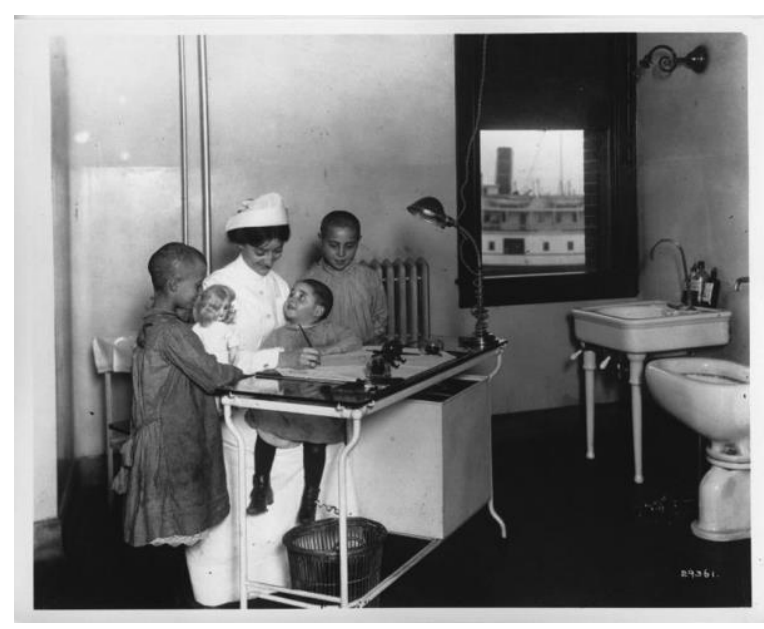

PHS nurse with immigrant patients. Courtesy of Save Ellis Island.
Nurse Corps who transformed the Ellis Island Hospital into a temporary supply depot, training center, and mobilization point.

The interned Germans arrived first. German and Austrian sailors were arrested upon America's declaration of war, and were transferred to Ellis Island for internment. Other German nationals suspected of espionage or sedition also found their way there over the course of the war.

From April 1917 to the end of the war, their numbers fluctuated between a few hundred to 1,170 persons, with some moved to other facilities to prevent overcrowding. They were quartered in the baggage and dormitory building, and treated very much like detained immigrants (though soldiers were sent out to guard them). Reports indicate decent treatment, their chief complaints being (ironically), "idleness and lack of beer." 57 The hospital was in an interesting position, as anyone who fell sick was treated in their facilities. Thus, internees, soldiers, sailors, and sick immigrants were all being treated in the same wards. Chief Nurse Margaret Daly commented on this in her memoirs, writing:

Those were stirring times at the Island. We had some trouble with the Germans, but on the whole, they were well behaved. The air was tense with unrest, however, and one felt that turmoil and violence might erupt at any moment. Looking back at the affair now seems like some horrible dream. Think of it! Enemy aliens, coastguardsmen, and militia, all comingled in the same hospital- some humorous, others sullen, and more anything but amenable to discipline. Many of the German interned were wealthy, some cultured, and practically all spoke English well. Several claimed to be members of the German aristocracy. It was indeed a cosmopolitan crowd, and many amusing and interesting situations developed which served to relieve the tension. ${ }^{58}$

\footnotetext{
${ }^{57}$ Unrau, 773.

${ }^{58}$ Margaret V. Daly, Nursing at Ellis Island, 2.
} 
The situations that developed were not always so amusing. Daly reported an instance when a drunken solider walked into a hospital ward with a loaded rifle. She recalled, "At one time a drunken soldier entered Ward No.1, which was used exclusively for women and children, and pointed a loaded rifle at each of the patients in succession, frightening them out of their wits. We had quite a task to calm the women and children and to get the drunken intruder out of their sight." ${ }^{, 59}$ Ellis Island in 1917 was a time of flux, with many diverse groups put in one place where they were not just ethnically different, but on different sides of a World War. Still, even greater changes were coming to the medical side of Ellis Island.

As America mobilized for war, the overwhelming shortage of nurses was shocking. When the war began, there were a mere 403 nurses in the Army Nurse Corps (ANC). In contrast, by spring of 1918, nearly one million men of the US Army had been deployed to France, with almost 10,000 more arriving each day. ${ }^{60}$ The Army's solution to the nurse deficit lay in partnership with the American National Red Cross Nursing Service. Through the Red Cross, trained nurses were recruited from around the country, and brought to central locations for mobilization. They were processed into the ANC, outfitted with necessary gear and uniforms for service, and transported overseas. This was overseen by ARC Nursing Service director Jane Delano and Clara D. Noyes R.N., the latter having formerly been in charge of Bellevue's nursing school (very close to Ellis Island in nearby Manhattan). ${ }^{61}$

The Army and Red Cross also set up a system of base hospitals. In the base hospital system, a mix of surgeons and other medical personnel were recruited from a civilian hospital, medical

\footnotetext{
59 Ibid., 3.

60 Jo-Ann Power, “Army Nurse Corps: Introduction, Purpose and Invitation to Contribute Content," Worldwarlcentennial.org, https://www.worldwar1centennial.org/index.php/army-nurse-corps-home.html (accessed November 11, 2019).

61 Roger Noyes, "Nurses We Remember: Clara D. Noyes," Worldwarlcentennial.org, https://www.worldwar1centennial.org/index.php/nurses-we-remember.html (accessed November 11, 2019).
} 
school, or other institution, and given a designation (e.g. Base Hospital No.30, the University of California School of Medicine unit). Local cities sponsored the base hospital, and assisted with funding and outfitting. ${ }^{62}$ Once mobilized and transported to Europe, the staff established their base hospital at a distance from the front lines. ${ }^{63}$ The base hospital system was vital to the Army Medical Corps in securing desperately needed personnel.

Ellis Island was designated as a mobilization center for nurses in June of 1917. The contagious disease hospital on Island No. 3 was turned over for use as a supply depot and living quarters for nurses awaiting embarkation to Europe ${ }^{64}$ Edith Agnes Mury was appointed the chief nurse and oversaw the transition. She had served in hospitals from the West Coast to the Philippines, along with three years in the Navy Nurse Corps. Transferred in 1916 to the ANC, she served for a time as assistant superintendent. In 1917, while on duty at the Mexican border, she was ordered to Ellis Island. After inspecting the massive hospital building, she and her assistant, Mina S. Keegan, hastily prepared for the Red Cross nurses already on their way. ${ }^{65}$

Soldiers stationed nearby at Governor's Island cleaned the hospital wards and converted them into dormitories. New arrivals slept on hospital beds. Besides the beds, there was almost no furniture, and newly arrived nurses lived out of their steamer trunks. ${ }^{66}$ The hospital accommodated around 500 nurses at that time. Meals were served in the dining hall on Island No.1, and entertainment (especially films) was provided by the Y.M.C.A in the famous great hall of the main

\footnotetext{
${ }^{62}$ Aaron J. Jackson, "Base Hospital No. 30, One Hundred Years Later - Part One: Organization, Mobilization, and Travel," Blogs.library.ucsf.edu, April 24, 2018, https://blogs.library.ucsf.edu/broughttolight/2018/04/24/base-hospital-no-30-one-hundred-years-later-part-one/ (accessed November 11, 2019).

${ }^{63}$ Marble, W. Sanders, et. al., "Delivery of Medical Care off the Battlefield Introduction," Worldwarlcentennial.org, https://www.worldwar1centennial.org/index.php/delivery-of-medical-care-off-thebattlefield.html (accessed November 11, 2019).

${ }^{64}$ Dock, 363.

${ }^{65}$ Ibid., 416.

${ }^{66}$ Ibid., 416-417.
} 
building. The movies were not just for the nurses, but also for the many other servicemen quartered on Island No.1, either guarding German internees or awaiting sailing orders. ${ }^{67}$

Life at Ellis Island could be incredibly exciting for these new Army nurses. Nurses without exception mustered at 9:00 am for roll call and drill. After that however, life was surprisingly free. On many days, shore leave was granted from roll call until midnight, unless a unit was under immanent sailing orders. ${ }^{68}$ For these women, many who were coming from diverse parts of the nation and had perhaps never traveled far from home, their time on Ellis provided a great opportunity to explore.

The diary of Elsie Blanche Augustine provides a glimpse into the daily life of the nurses mobilized on Ellis Island. Augustine volunteered for the ANC as part of Base Hospital No.23 of Buffalo, New York. ${ }^{69}$ Typically, nurses of a base hospital were separated from the other personnel, sent to Ellis Island for outfitting, and reunited with their unit in Europe. ${ }^{70}$ Augustine arrived at Ellis for mobilization on August 29 $9^{\text {th }}$ 1917. Off-island excursions were common for the nurses. Her diary recounts many that she and her compatriots made while quartered there from August $29^{\text {th }}$ to November $22^{\text {nd }}, 1917 .^{71}$ She describes trips to vaudeville and to various plays and movies. She and her friends frequented many restaurants, even having lunch at the famous Waldorf Astoria hotel. Some excursions went beyond New York City, as she reports taking day trips up the Hudson to Bear mountain, and to visit family in nearby Bayonne, NJ. ${ }^{72}$

\footnotetext{
${ }^{67}$ Glenna Lindsley Bigelow, et. al.,. "Ellis Island From Three Points of View," The American Journal of Nursing 18 (October, 1917): 613-622.

${ }^{68}$ Dock, 417.

${ }^{69}$ Transcription of personal diary of Elsie Blanche Augustine [Hock], HOM-006, Elsie Blanche Augustine collection, 1917-1919, The Robert L. Brown History of Medicine Collection, University at Buffalo, The State University of New York (shared courtesy of Ann Mckibbon and Fred Voss), 2.

${ }^{70}$ Jackson, "Base Hospital No. 30, One Hundred Years Later - Part One: Organization, Mobilization, and Travel." Blogs.library.ucsf.edu.

71 Augustine, Diary, 2.

72 Ibid., 18-37.
} 


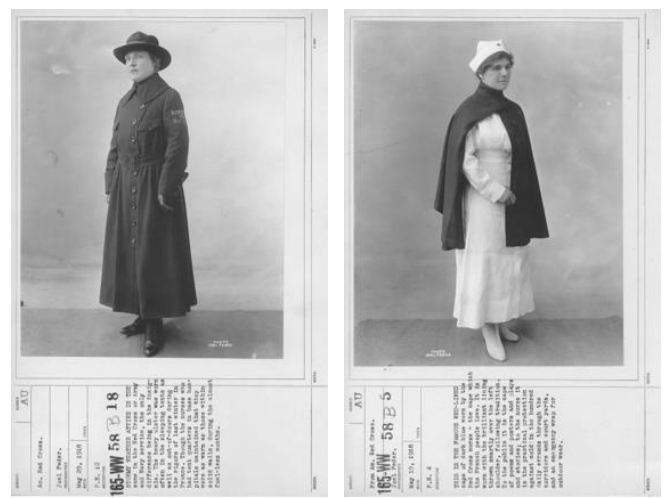

The blue outdoor uniform and standard uniform. Note the cape for active duty.

Courtesy of the American unofficial collection of World War I photographs, 1917-1918, National Archives.
Augustine also relayed the excitement of being fitted for uniforms. There were three kinds she encountered. The outdoor uniform was a dark blue Norfolk suit and skirt, blue felt hat, arm brassard, and a blue flannel cape lined with scarlet fabric. The standard white uniform of the red cross nurse (which is iconic and easily recognizable) was also issued as they were called up for active duty, and in times of war a blue cape was

issued to be worn with this uniform. The cape was a source of immense pride. An outward mark of their service, only nurses on active duty during the war were allowed to wear it. For them, the cape and the brassard on their arms that bore the red cross insignia embodied the honor and sacrifice of war nursing. ${ }^{73}$

The third variation, the grey uniform (more of a work uniform that was worn indoors), was not as beloved. It was a grey cotton crepe dress, worn with a white pique collar and cuffs, a brassard, and a cap. ${ }^{74}$ Augustine admitted her dislike succinctly, writing, "To city to be fitted for grey uniforms - horrible affairs."75 Nurses were outfitted with all the gear they would need overseas, like spare uniforms, cold weather gear, overcoats, rain jackets, rubber boots, and sleeping bags. ${ }^{76}$ The sight of the nurses laden with so much gear made an impression on ANC

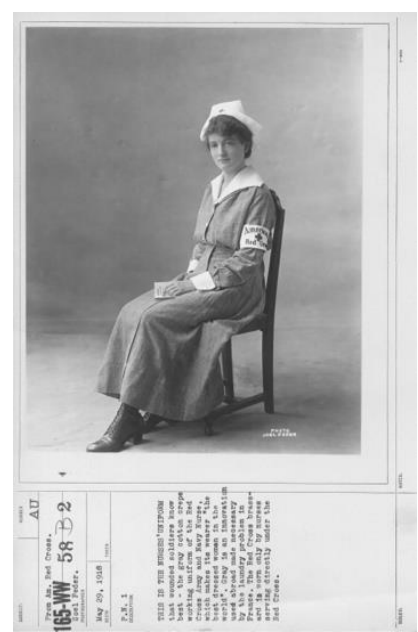

The grey work uniform. Courtesy of the American unofficial collection of World War I photographs, 1917. 1918, National Archives.

\footnotetext{
${ }^{73}$ Dock, 358.

74 Shirley Powers, "A Guide to American Red Cross Uniforms," Collectarc.com, April, 2006, http://www.collectarc.com/Uniform\%20Guide.pdf (accessed November 11, 2019).

75 Augustine, Diary, 19.

${ }^{76}$ Dock, 372.
} 
Superintendent, Dora E. Thompson. She described the scene as a group of nurses embarked for

\section{Europe:}

Sometimes we'd crawl out of bed at three A.M. and drive down to the East River or over to Hoboken to meet the nurses on the docks. Often it would be raining in torrents. Again the cold sleet numbed us. Our arms were always piled high with every conceivable kind of bundle. We Red Crossers had great difficulty in getting supplies to the other side, so every nurse en route to the Paris office, went laden down with bundles, and resembled an immigrant at Ellis Island. ${ }^{77}$

It was variable how long nurses had to stay on Ellis Island. Due to the shortage of ships, authorities gave precedence to troops and supplies. Sometimes a few weeks, or months, passed before sailing orders came in (Augustine waited nearly three months) ${ }^{78}$ On October $1^{\text {st }}$, she wrote, "We're still here-will we ever go?"79 While they waited, nurses were given orientation presentations, immunizations, and were instructed in drill and military life. ${ }^{80}$ Basic lessons in French were arranged, which paid off during her service when she encountered numerous French children and even Algerian patients. ${ }^{81}$ They were also paid, and quite well by the day's standards. Augustine reported, "we were paid today - all feel like millionaires with fifty dollars." Dr. Ann McKibbon, in her commentary on her aunt's diary explains, "This was considerably higher than most salaries, especially for women, in the US at that time. Once the nurses arrived in Europe their pay increased to $\$ 60$ per month. They were given a raise in August 1918 up to $\$ 70 /$ month. The cities and the Red Cross funded the hospitals - salaries came from the US Army." 82

When orders finally came, a flurry of activity occurred as shore leave and communication with friends and family were suspended. ${ }^{83}$ Equipment was hastily assembled, and one can imagine

\footnotetext{
${ }^{77}$ Ibid., 423.

${ }^{78}$ Ibid., 419.

${ }^{79}$ Elsie Blanche Augustine, Diary, 25.

${ }^{80}$ Dock, 419.

${ }^{81}$ Augustine, Diary, 47, 60.

82 Ibid., 25.

${ }^{83}$ Dock, 423.
} 
the feelings of excitement and trepidation as the ferry arrived. A decided optimism seems to have been a defining mark among them. Chief nurse Mury recalled scenes of nurses departing Ellis Island:

Usually as the boat shoved off a lilting song came drifting back, "Pack up your troubles in your old kit bag and smile, smile, smile." One knew, however, that the wonderful spirit of American womanhood strengthened by hospital training enabled those nurses one and all to face so bravely the journey across the submarine-infested sea and the further unknown dangers of military hospital duty in a war-stricken foreign land. ${ }^{84}$

Growing from only 403 nurses when the war began, the ANC, through combined efforts with the Red Cross, recruited 22,400 women. ${ }^{85}$ Over 10,000 of these nurses served overseas, passing through Ellis Island and New York City to be equipped for the struggle ahead. ${ }^{86}$ Augustine and her comrades from Base Hospital No.23 spent their time overseas working in Vittel, France. Her diary offers a glimpse into hospital life as the war's final offensives began. On September $14^{\text {th }}$, 1918, during the battle of St. Mihiel, she wrote, "Very busy. Operating day and night. So many amputations. Surgeries look like slaughterhouses." ${ }^{87}$ Though Augustine survived, more than 200 nurses did not return home, some of Augustine's comrades among them. ${ }^{88}$ Today, they lie in American cemeteries abroad, having made the ultimate sacrifice in the effort to nurse back to health nearly 320,000 American soldiers. ${ }^{89}$

\section{Brimful of Pep, Enthusiasm, and Hope: USA Debarkation Hospital No.1}

As huge numbers of sick and wounded returned from the war, Ellis Island's mission changed once more. As they returned, a series of debarkation hospitals were established to

\footnotetext{
${ }^{84}$ Ibid., 424.

${ }^{85}$ Power, "Army Nurse Corps," Worldwarlcentennial.org.

${ }^{86}$ Dock, 423.

${ }^{87}$ Augustine, Diary, 79.

${ }^{88}$ Ibid., 80-81.

${ }^{89}$ Power, “Army Nurse Corps," Worldwarlcentennial.org.
} 
temporarily treat them once removed from transport ships, to the point they were evacuated to more permanent military bases and hospitals. Ellis Island was the first in this series of hospitals, designated Debarkation Hospital No.1 ${ }^{90}$ Four additional hospitals were also established in the port of New York. They were Debarkation Hospital No.2 (Fox Hills, Staten Island), No.3 (the SiegelCooper department store or "Greenhut" building on Sixth Avenue in Manhattan), ${ }^{91}$ No.4

(Long Beach, Long Island), and No.5 (Grand Central Palace, Manhattan's prime exhibition hall on Lexington Avenue, between $46^{\text {th }}$ and $47^{\text {th }}$ streets $\left.{ }^{92}\right) .{ }^{93}$

Beginning in February 1918, the War and Navy departments requisitioned the island's buildings. Debarkation Hospital No.1 opened to receive patients on March $8^{\text {th }}, 1918 .^{94}$ The Red Cross nurses who had used the island as their mobilization station, evacuated, and took up quarters in New York City hotels. ${ }^{95}$ The hospital was staffed by the men and women of the Army Medical Department and the Red Cross. The Army converted the famous great hall on Island No.1 into a 260 bed hospital ward, utilized the general hospital for 280 patients of a surgical nature, and the contagious disease hospital for an additional 500 patients. The complex could accommodate around 1,000 patients at a time. ${ }^{96}$

Unfortunately for the Immigration Service and the PHS, their space on the island was relegated to only three rooms, and a small portion of the baggage and dormitory building for the

\footnotetext{
${ }^{90}$ Frank W. Weed, The Medical Department of the United States Army in the World War, Vol. 5 (Washington: Government Printing Office, 1921-1929), 426-429..

91 Tom Miller, “"The Big Store'-1896 Siegel-Cooper Department Store,” Daytoninmanhattan.blogspot.com, August 23, 2010. http://daytoninmanhattan.blogspot.com/2010/08/big-store-1896-siegel-cooper-department.html (accessed November 26, 2019).

92 David W. Dunlap, "When Trade Shows were Both Grand and Central," Cityroom.blogs.nytimes.com, December 18, 2012. https://cityroom.blogs.nytimes.com/2012/12/18/when-tradeshows-were-both-grand-and-central/ (accessed November 26, 2019).

${ }^{93}$ Weed, 429.

${ }^{94}$ Ibid., 792.

${ }^{95}$ United States Department of War, Report of the Surgeon General, U.S. Army, to the Secretary of War, 1918 (Washington D.C.: Government Printing Office, 1918), 431.

${ }^{96}$ Weed, 792.
} 
accommodation of around 600 immigrants. Medical inspections during this period were conducted by PHS officers on-board ship: an immense logistical challenge. For immigrants who needed medical treatment, there were two prospects. The PHS was expected to find accommodations for them in private hospitals, and by June of 1919, immigrant patients were scattered across 28 hospitals in the New York City area. Immigrants who fell ill in detention on Ellis were treated in the hospital there by the Army staff. ${ }^{97}$ Great frustration was expressed by the PHS, as it was nearly impossible to make satisfactory medical examinations, and equally difficult to find available beds in already-crowded city hospitals.

Major Chester R. Haig of the Army Medical Corps oversaw the hospital, and he was supported initially by a small enlisted force of 107 . The month of March 1918, was hard to bear, as the personnel experienced shortages of warm clothing and cooks. However, both supplies and personnel would increase over time, and by September $4^{\text {th }}$ the staff numbered over 300 . By Christmas of 1918, the staff also included four majors, 10 captains, 26 first lieutenants, one hospital sergeant, 12 sergeants first class, 35 sergeants, 16 corporals, and 18 cooks. ${ }^{98}$ They were all soon strained by the arrival of troopship after troopship, delivering thousands of men borne on stretchers into their care.

Hard data on cumulative numbers of men treated at Ellis Island is quite scarce and inconclusive. Only scattered references survive. These sources give the impression that the number is possibly in the low thousands, and contemporary accounts describe a brisk tempo of operations. In the last week of January 1919, the hospital was filled to capacity with almost 1,100 patients. By the week's end, just 200 remained, the rest having been evacuated to other military hospitals. Lt.

\footnotetext{
97 Unrau, 791-796.

98 The Pill Box, Souvenir Edition, New York City: The Exchange for the Medical Detachment, U.S.A. Debarkation Hospital No.1, December 25, 1918, The Bob Hope Memorial Library.
} 
W. H. Seward claimed that 200 patients could be processed into the hospital every hour ${ }^{99}$ (which seems to have been the record among the five debarkation hospitals), and turnaround time between admission to evacuation could be a mere three days. ${ }^{100}$

The most symbolic act emphasizing the island's change of mission from immigration to the treatment of soldiers, was the conversion of the great hall into a hospital ward. On paper it was Ward 34, but to the inhabitants it was "The Big Ward.” A 260 bed ward, it handled surgical, ambulatory, and some psychiatric cases. That 1,000 blankets, 1,500 sheets, 800 bath towels, and 500 suits

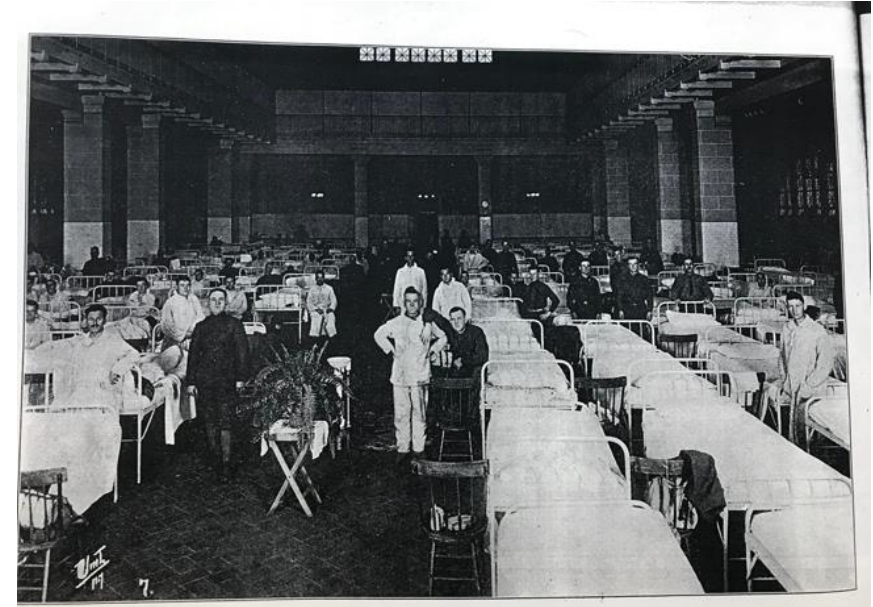

The great hall converted to a hospital ward, 1918. Photo from the Pill Box. Courtesy Ellis Island National Museum of Immigration, National Park Service.

of pajamas were always on hand gives an idea of scale. The ward was run by Head Surgeon Lt.

Carl H. Robinsteen (known around the place as "the man with the million-dollar smile"). ${ }^{101}$

Caring for these men was no small undertaking. But who were they, and what did they suffer from? An account of the first patients received explains how many were shell-shock cases or had been badly maimed. ${ }^{102}$ Another account from Carry On, a publication for wounded soldiers, gives this description:

Two Buck Privates [sic] from the corn-fed belt of the Middle West [sic], one with his right leg missing and the other minus his left, clacked along one of the walks with the aid of crutches and the peg-legs which temporarily are taking the place of the artificial legs that soon will be fitted to them at the Walter Reed Hospital in Washington. Seated on the stone steps as the two clacked along were the armless and legless and those whose limbs hung limp because bullets or high explosives

\footnotetext{
${ }^{99}$ Unrau, 797-798.

100 The Pill Box, December 25, 1918.

101 Ibid.

102 Unrau, 796.
} 
had shattered important nerve tissue which soon, through science, will be made whole again. ${ }^{103}$

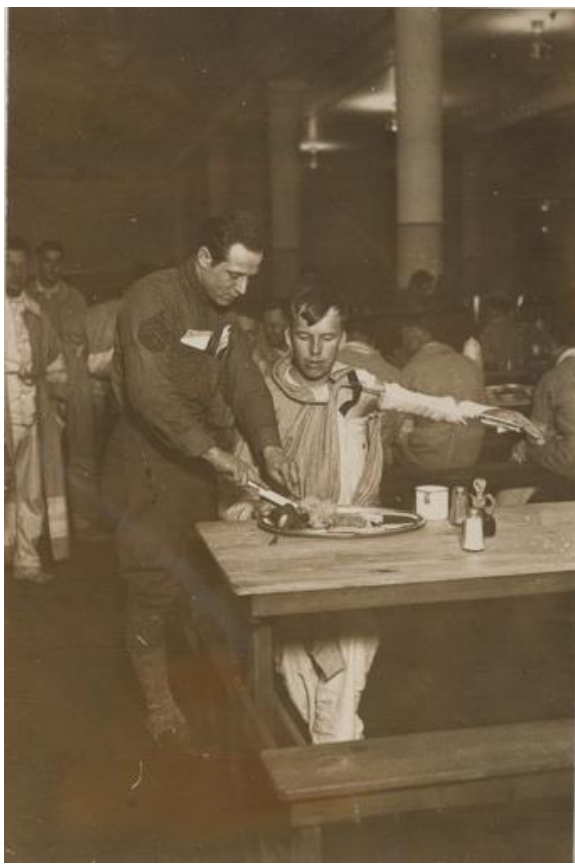

A common sight at all of the debarkation hospitals, helping an injured soldier to eat. Taken at Debarkation Hospital No.3. Courtesy of the American unofficial collection of World War I photographs, 19171918, National Archives.
For their comfort and morale, the Red Cross provided books, writing materials, games, musical instruments, fruit, candy, tobacco, and even theater tickets to those well enough to travel. ${ }^{104}$ The Red Cross also screened movies in a tent on Island No.3, and eventually built a more permanent brick building for entertainment on Island No.2 that opened on Christmas Day 1918 to great excitement (the building no longer stands). ${ }^{105}$ It was also common for the men of other debarkation hospitals to get together for athletic meets, passing some time and building morale. Often, the men of Fox Hills (Debarkation Hospital No.2) faced off against the men on Ellis Island in these athletic competitions. ${ }^{106}$ The men even formed their own band. An announcement in the hospital's selfpublished newspaper, The Pill Box, reads, "NOTICE TO THE ISLANDERS OF ELLIS [sic]: The nameless orchestra of the Island has had an addition of a slide trombone and cornet,[sic] with this new combination we will put the ' $\mathrm{J}$ ' in Jazz."107

The Pill Box deserves some commentary, as it is one of the few sources about daily life on the island, and contains many insights despite the fact that only a few pages survive. All of the

\footnotetext{
${ }^{103}$ Frank Ward O’Malley, "Home Comers from France," Carry On: A Magazine on the Reconstruction of Disabled Soldiers and Sailors 1 (September, 1918): 1-10.

104 The Pill Box, December 25, 1918.

105 The Pill Box, Volume 1. No.8, New York City: The Exchange for the Medical Detachment, U.S.A. Debarkation Hospital No.1, December 31, 1918, The Bob Hope Memorial Library.

106 The Pill Box, Volume 1. No.2, New York City: The Exchange for the Medical Detachment, U.S.A. Debarkation Hospital No.1, September 14, 1918, The Bob Hope Memorial Library.

${ }^{107}$ Ibid.
} 
hospitals self-published their own papers, ${ }^{108}$ which not only recorded the news, but also the gossip (this was, after all, intended to amuse as well as inform the reader). Embarrassing stories and humorous anecdotes about army life and their fellow soldiers all found their way into The Pill Box.

No mercy was shown to Cpl. Hunter Darling after a mishap involving his trousers:

Corporal Hunter Darling, of the Guards, had a very distressing experience one night last week. He had a very heavy date in Newark and armed with a forty-eight-hour pass, started out to keep his engagement. Alas! Hardly had the morning sun kissed the placid waters of the harbor next day when he [sic] saw a very down-hearted Corporal returning to the Island-minus his khaki trousers! Oh, yes, he was wearing a pair of woolen O.D.'s, about three sizes too large for him, which he had purchased at some second-hand store on the East Side. How his trousers were stolen or where, he refused to tell; and natural delicacy caused us to refrain from asking any questions which might embarrass him. ${ }^{109}$

Despite good humor, no facility was safe from the Influenza epidemic that raged around the globe killing an estimated 50 million people. ${ }^{110}$ Again, a few scattered sources provide glimpses into the influenza situation at Ellis Island. The first cases appeared at Ellis Island around September $20^{\text {th }}, 1918$. From then until June 30, 1919, it was reported to the Secretary of War that 232 "isolations" were made, and that 24 developed pneumonia, with six deaths resulting. ${ }^{111}$ To get a much broader glimpse at the situation in the area, look to nearby Hoboken, a major port of embarkation for American troops. At that port, there were some 17,000 cases of influenza treated, with approximately 4,000 of them developing pneumonia. ${ }^{12}$ The influenza epidemic was certainly severe in the general area of Ellis Island at that time.

\footnotetext{
108 Weed, 168-169.

${ }^{109}$ The Pill Box, Volume 1. No.1. New York City: The Exchange for the Medical Detachment, U.S.A. Debarkation Hospital No.1, August 31, 1918, The Bob Hope Memorial Library.

${ }^{110}$ Centers for Disease Control and Prevention. "1918 Pandemic (H1N1 virus)." Cdc.gov. https://www.cdc.gov/flu/pandemic-resources/1918-pandemic-h1n1.html (accessed 11/25/19).

${ }^{111}$ United States Department of War, Annual Report of the Secretary of War, 1919, Vol.1, Part 2, Report of the Surgeon General (Washington D.C.:1920), 2174.

112 Ibid.
} 
By February 1919, Debarkation Hospital No.1 was designated the primary hospital for contagious diseases. ${ }^{113}$ The term "isolations" is quite relevant, as it reflects good procedure on the part of the Army Medical Department in handling the situation. It was standard practice on the island to isolate anyone who showed any signs or symptoms of disease. Large numbers of diphtheria carriers among returning troops compounded an already precarious situation, and led to the practice of all patients at the debarkation hospitals having throat cultures and temperatures taken before admission to a ward. ${ }^{114}$ The isolation of contagious patients who might otherwise have escaped detection likely saved many lives.

Though Ellis was designated the treatment center for the majority of contagious cases from the other debarkation hospitals, the danger of the epidemic required extra measures. ${ }^{115}$ A steamboat was procured in late 1918. The General O'Reilly was 202 feet long, and 40 feet at the beam, and was tied up at Pier 45, North River, Manhattan. Onboard, 274 patients could be separated into nine wards, with a staff of 11 commissioned officers, 20 Army nurses, 84 enlisted men, and a crew of 43. Very limited statistics state that 606 patients were treated on the ship before its use was completed on April 15, $1919 .{ }^{116}$ With the availability of the hospital ship, Ellis Island treated the overflow of patients, and housed patients who had begun to recover. ${ }^{117}$

The medical staff also suffered losses. The Pill Box dedicated a page to members of the detachment lost while tending the sick and wounded. By Christmas of 1918, five members had died. Two Army nurses, Katherine Connolly and Mary J. Scheirer, passed away on August $27^{\text {th }}$ and October $6^{\text {th }}$ of 1918 respectively. Three men of the medical detachment, Pvt. Loren H. Koontz,

\footnotetext{
113 Unrau, 798.

114 Weed, 271.

115 Unrau, 798.

116 Weed, 319.

${ }^{117}$ Ibid., 271.
} 
Pvt. Edward O'Rourke, and Pvt. $1^{\text {st }}$ Class Herman A. McLeland, died April $27^{\text {th }}$, September $30^{\text {th }}$, and December $7^{\text {th }}$ of 1918 respectively. ${ }^{118}$ At least two of them, Mary J. Schreier ${ }^{119}$ and Herman A. McLeland, ${ }^{120}$ certainly died of influenza. A tribute to Katherine Connolly, and to the kind work of the medical staff, appeared in The Pill Box after her sudden passing.

We are as a large family, in our daily fellowship with each other; our Nurse Corps is responsible for this spirit of good will and enthusiasm, as by their patience and care they have won many a fight with Death and have saved some soldier for a further life of service and for his people. While men can hardly reconcile the fact that anyone doing so much valuable service should be called away from her work [sic] we feel that One alone knoweth best, and that she will receive the great reward promised to the faithful steward. ${ }^{121}$

A line in the Christmas edition remarks, "While the influenza hit us hard, we fought it through with no impairment of morale or efficiency." ${ }^{122}$ One certainly gets the idea that the staff on Ellis Island knew the danger of their situation and that a tough job lay ahead. From the same edition it reads, "To every one of the Detachment, the Christmas message of The Pill Box is Cheero-and good luck!"123

The end of the war brought excitement, relief, and also frustration. A satirical obituary appeared following the armistice which reads, "Died-Some time [sic] in the wee small hours of last Monday morning, all hope of this Detachment ever going to France. With sorrow we are now forced to admit that it is in fact 'all over." "124 The newspaper describes the celebrations of the wounded men on November $12^{\text {th }}$, the article titled, "One of the most pathetic and inspiring

\footnotetext{
118 The Pill Box, December 25, 1918.

${ }^{119}$ Barry Kauffman, “Mary J. Scheirer,” Findagrave.com, January 6, 2011, https://www.findagrave.com/memorial/63828974 (accessed 11/25/2019).

${ }^{120}$ John C. Anderson, "Herman A. McLeland," Findagrave.com, January 11, 2010, https://www.findagrave.com/memorial/46574987/herman-a-mcleland (accessed 11/25/2019).

${ }^{121}$ The Pill Box, August 31, 1918.

122 The Pill Box, December 25, 1918.

${ }^{123}$ Ibid.

124 The Pill Box, Volume 1. No.6. New York City: The Exchange for the Medical Detachment, U.S.A. Debarkation Hospital No.1, November 23, 1918, The Bob Hope Memorial Library.
} 
demonstrations was witnessed on Ellis Island." The wounded men, some propped up on crutches, in wheelchairs, or even carried on stretchers, marched out of the hospital, cheering and singing. A band was assembled from the men, and an effigy of the Kaiser hastily fashioned out of bedclothes. The cloth Kaiser was carried on a stretcher as the band followed playing a funeral dirge, the nurses and doctors marching along behind the procession. The men buried the Kaiser in a hastily dug grave, "boo-ed" loudly three times, then marched back as the band played "Garry Owen" and "When the Boys Come Home."125

Despite the celebrations, tension mounted as the medical personnel sought to obtain discharges and return to civilian life. However, the great number of sick and wounded returning from France following the armistice necessitated that they stay on duty. An appeal from the Surgeon General was published, imploring the medical staff "both commissioned, and enlisted, to be patient, to do the work that is to be done to the best of its ability, and to make still further sacrifices if this is necessary in order that the sick and wounded may be given the treatment which has been promised them by the Department."126

The Detachment stayed the course, taking care of the returning soldiers. Still, they satirized the situation and released a message in The Pill Box that fairly sums up how they felt. They called it, "The Ellis Island Prayer":

Our Father who art in Hoboken give us our honorable discharge and forgive us our A.W.O.L.'s [absent without leave] as we forgive the Mess Sergeant, the Bugler, and all those who wear bars. Tempt us not with the Eves who love only our brass buttons but deliver us unto our wives, sweethearts and mothers.

All this we ask in the name of your son, Saint Clair [Capt. G. G. St. Clair M.C.], who has gone before us that he might prepare a place for us in the kingdom of civilians. AMEN [sic]. ${ }^{127}$

\footnotetext{
125 Ibid.

126 The Pill Box, Volume 1. No.12. New York City: The Exchange for the Medical Detachment, U.S.A. Debarkation Hospital No.1, March 15, 1919, The Bob Hope Memorial Library.

${ }^{127}$ Ibid.
} 
The medical staff of Debarkation Hospital No.1 waited until the summer of 1919 to get their wish. The Army began to evacuate and return the buildings on April $1^{\text {st }}, 1919$, beginning with the main building on Island No.1. ${ }^{128}$ This caused some overcrowding for a time, as the Army was relegated to the use of just the hospital complex on Islands No.2 and No.3. ${ }^{129}$ By June $30^{\text {th }}$, the Army had withdrawn completely, and the PHS then had to face the challenge of re-outfitting their hospital for the purpose of treating immigrants and beneficiaries once more. ${ }^{130}$ As this era in the island's history came to a close, it is the excellent care that returning soldiers received that makes the greatest impression. Sergeant First Class Driver, a patient at the hospital wrote, "To send you on your way rejoicing, and brimful of pep, enthusiasm, and hope - that is the mission of U.S.A Debarkation Hospital No.1, and take it from me, Buddy, they know how to instill it into you."131

\section{Conclusion: What Did You Do in the War?}

For those present on Ellis Island during the period of the First World War, there were many ways they looked back on their service. For the PHS personnel who were present during the Black Tom Incident, many looked back with a mix of disbelief at the events that had transpired, and great pride in the courageous actions that they took to protect their immigrant patients (and even the island itself). The thousands of Red Cross nurses who passed through likely remembered their time on the Island as one of excitement, whether it was being fitted for uniforms or visiting a big city for the first time, anticipation of what awaited them overseas, and boredom when they had to wait long periods for sailing orders that, sometimes, just never seemed to come in. For the Army's medical personnel, they, like every soldier, wondered what they would tell their children when

\footnotetext{
${ }^{128}$ Unrau, 798.

129 The Pill Box, March 15, 1919.

${ }^{130}$ Unrau, 798.

${ }^{131}$ The Pill Box, December 25, 1918.
} 
they asked, "what did you do in the war?" The answer they gave to that exact question was, in typical fashion, laced with familiar Army humor. In The Pill Box they wrote:

Victory is ours at last! Men of Ellis Island we are proud of you. Hoboken is proud of you. You have displayed courage, not under shell fire but by riding on [sic] the Bronx and travelling on the subways and street cars of New York City. Many a day you had to go with but three meals and then as night appeared you had nowhere to sleep but in a comfortable bed. Many of you have subjected yourselves to eye-strain witnessing shows. Others have been gassed in New York City and refused absolutely to wear gas masks. But the reward is yours. Just think how proud you will be when a little Johnny says; "What did you do, Dad?" And you say you had your feelings injured in the battle of Hoboken. Citations, chevrons, etc., are on hand for those who have nerve to call for them. ${ }^{132}$

Though they joked, in truth they had fought a war. Whether in an immigrant patient or a soldier, they fought a war against disease, an invisible enemy they were almost unable to see, and in some cases as powerless to treat. They also fought a war of morale. The challenge of restoring maimed, wounded, and sick soldiers back to a state of physical health was only half the battle.

Instilling and maintaining a sense of optimism, and the hope that these men could lead productive and fulfilling lives despite their injuries, proved to be just as great of a challenge. The war against disease and despair was a war in itself, whether it was fought by the PHS, the Red Cross, or the

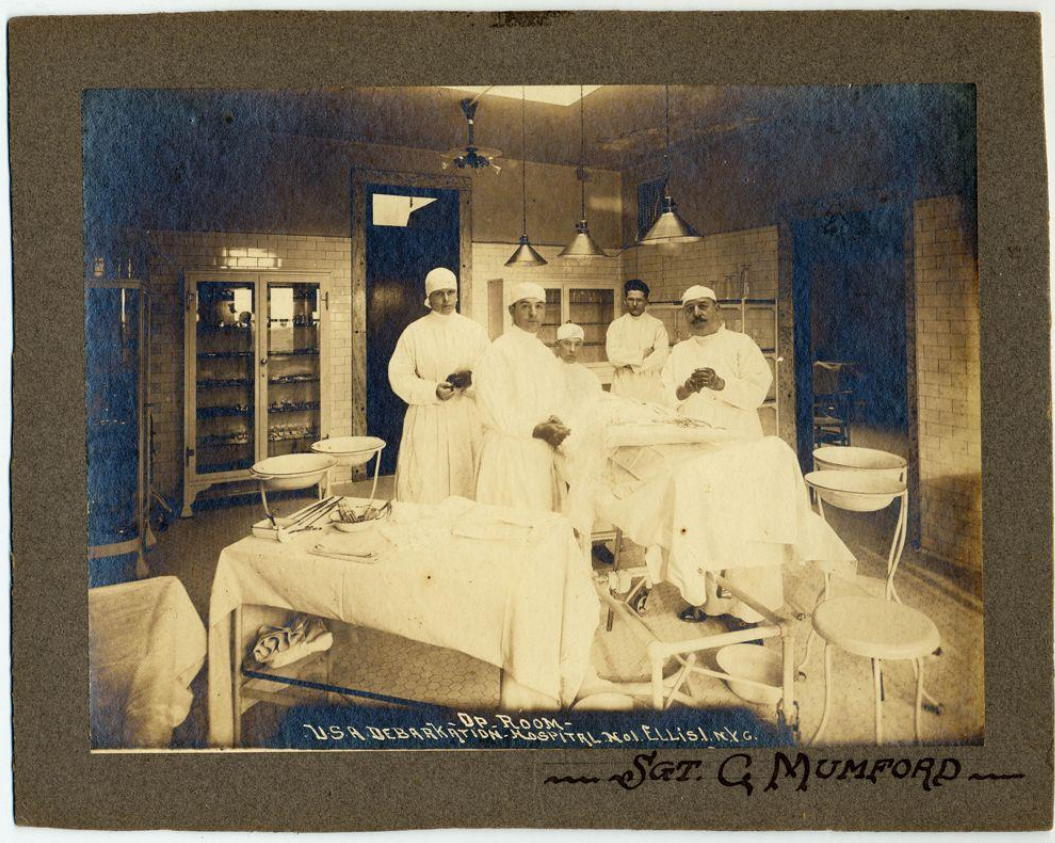
Army Medical Department. When Army Surgeons in one of the operating rooms of the General Hospital. Courtesy of Save Ellis Island. the going was tough, these resolute

\footnotetext{
132 The Pill Box, November 23, 1918.
} 
men and women showed how to live the lyrics: "Pack up your troubles in your old kit bag, and smile, smile, smile!"

Ryan Radice, a New Jersey native, is a graduate student working on his M.A. in History at Monmouth University, where he also completed his undergraduate work. His areas of study are varied and include everything from the history and archaeology of New Jersey cemeteries to the history of immigration and medicine in late $19^{\text {th }}$ and early $20^{\text {th }}$ century America. Since 2018 , he has worked with the New Jersey-based organization Save Ellis Island to interpret the history of Ellis Island's abandoned immigrant hospital complex. 